This is an Accepted Manuscript of an article published by Taylor \& Francis in Scandinavian Journal of History on 10 August 2020, available at https://www.tandfonline.com/doi/full/10.1080/03468755.2020.1788633

\title{
The Elusive Finn: Ethnic Identities, Source Criticism and the Early History of Northern Sweden in Seventeenth-Century Swedish Historiography
}

Samu Sarviaho ${ }^{\text {a* }}$

${ }^{a}$ History of Sciences and Ideas, University of Oulu, Finland

samu.sarviaho@oulu.fi

Samu Sarviaho is a post-doctoral researcher in the History of Sciences and Ideas at the University of Oulu, Finland, specialising in the history of historiography. His current research project - funded by the Finnish Cultural Foundation - examines conceptions in Finnish and Swedish historiography (ca. 1600-1999) surrounding the origins of early Finnish settlement in Northern Finland and Northern Sweden. 


\title{
The Elusive Finn: Ethnic Identities, Source Criticism and the Early History of Northern Sweden in Seventeenth-Century Swedish Historiography
}

\begin{abstract}
The earliest history of the Swedish Realm's northern regions has long been contested in historiography. This article primarily analyses views in seventeenthcentury Swedish historiography concerning the origins of Finns in this region, in terms of source usage and ethnic identities. Gothicist views, emphasising Swedish greatness were based on biblical notions of a postdiluvial settlement, linking sources from classical antiquity to Sweden via etymological comparisons. Combined with a reliance on Icelandic sagas and the uncritical use of secondary sources, these notions gave rise, among others, to the idea of an ancient, partially Finnish, Amazon warrior realm in Ostrobothnia. Conceptions surrounding the origins of Birkarl tax collectors were mostly based on traditions collected in the early 1600 s, and later that century, they became associated with a migration of Finns to the north thought to have taken place in the late $13^{\text {th }}$ century. Finns were given a role in the region's history even within Gothicist historiography too. The ethnicity of these early settlements does not seem to have been overly emphasized though - indeed the boundary between Finns and Swedes was seen more as something fluid - indicating that ethnosymbolist theories of nationalism overstate the importance of ethnic identity in early modern Sweden.
\end{abstract}

Keywords: $17^{\text {th }}$ century, ethnic identities, Finland, Gothicism, history writing, Sweden

\section{Introduction}

In 1910, Arvi Ahmavaara - a Finnish lawyer and the future Minister of Justice for Finland, ${ }^{1}$ wrote a description of his home parish, Ii, in Northern Ostrobothnia. At the beginning of the book, he briefly described previous theories on the history of this locality. He ridiculed the views presented by a seventeenth-century Swedish author, Olof Rudbeck the Elder, who saw the region as having once been the home of King Inachus, his daughter, Isis, and the Cimmerian people. According to Ahmavaara, charming as these views were in all their quirkiness, they should not be taken seriously. ${ }^{2}$ 
The views presented by both Ahmavaara and Rudbeck were links in a chain that went back a long way. Despite Ahmavaara's claims, the theories of Rudbeck were no laughing matter in the context of seventeenth-century historiography. The origins of the those living in the North of the Swedish realm have been a source of contention in Nordic historiography for a long time, and yet they have been rarely analysed from a historiographical point of view. ${ }^{3}$ Norwegian historians, Teemu Ryymin and Per Pippin Aspaas, analysed conceptions surrounding the origins of the northern Kvens presented by late eighteenth-century Finnish historian, Henrik Gabriel Porthan, in an article published in 2010. They concluded that, since the $19^{\text {th }}$ century, Finnish and Swedish historians have sought to 'ethnonationalise' peoples mentioned in the oldest historical writings; in other words, centre them specifically on their own ethnic group rather than any other. ${ }^{4}$

This article analyses seventeenth-century conceptions in Swedish historiography concerning the earliest origins ${ }^{5}$ of Finns in the two northern provinces of Västerbotten (Westrobothnia) and Österbotten (Ostrobothnia). ${ }^{6}$ In the $17^{\text {th }}$ century, Ostrobothnia could be seen as being part of Finland in geographical and ecclesiastical terms, but not in terms of administration or representation. In most $17^{\text {th }}$ century cartography, the concept of Finland itself was vague and confined to what we would now call South-Western Finland. ${ }^{7}$ I aim to discover: (i) the kinds of views that were presented on the origin and nature of Finns in these regions; (ii) the factors regarding source usage which influenced them; and, most importantly, (iii) whether views such as these, from as early as the $17^{\text {th }}$ century, can truly be characterised as ethnonationalist.

To better assess the degree of ethnonationalism, one must consider the debate, primarily carried out at the beginning of the 2000s, surrounding early modern ethnic or national identity in Sweden and its possible effects on historiography. A popular view on the subject is based on the 'ethnosymbolist theory of nationalism'. According to the late 
British sociologist Anthony D. Smith, nations are based on pre-existing ethnic communities, or ethnies, which share a name, culture, myths of common descent, historical memories, a connection to a certain historic homeland, and a measure of solidarity - at least among the elite. ${ }^{8}$ A commonly held view is that the upper echelons of Swedish society considered themselves to be Swedish from as early as the late Middle Ages, and that the Swedes were a people united by their shared language and historical origins. $^{9}$

The Swedish historian, Jonas Nordin concluded in 2000 that early modern Swedish elites shared a well-developed sense of national identity. Operating firmly within the ethnosymbolist framework, Nordin went on to claim that though Finland was also part of the Swedish realm it was seen as a separate part of it - Finns and Swedes were not considered related. It was only in the $19^{\text {th }}$ century that cultural and political notions of a unified people and nation were consistently applied together as a basis for nationalism in Sweden. ${ }^{10}$ In her doctoral thesis from 2006, focusing primarily on the study of material antiquities in seventeenth-century Sweden ${ }^{11}$ (and conforming to the ethnosymbolist model), Johanna Widenberg concluded that antiquities were also used in attempts to integrate 'ethnic' Swedes within Sweden proper, while the Finns to the east of the Gulf of Bothnia were, for all intents and purposes, excluded from these efforts. ${ }^{12}$

Other views challenging the ethnosymbolist conception have arguably been more important in the debate. According to Jouko Nurmiainen, Finland was not considered a separate part of the Swedish realm, nor would it be appropriate to speak of distinct ethnies in early modern Sweden; rather it was patriotism, i.e. affection towards the Swedish state (rather than its inhabitants), that was the more significant factor. ${ }^{13}$ Meanwhile, Harald Gustafsson argues that ethnic identities were merely one part of the puzzle in early modern Sweden - other factors, such as regional identity and religion, were also 
important. It was only later on, with the rise of the nation state, that a relationship needed to be forged between political units and ethnicity. ${ }^{14}$

According to Bo Lindberg, religion was the most important factor in maintaining cohesion of the realm. The 'fatherland' was also an important object of identification, and it had ethnic connotations too: it could mean the realm in general (mostly Sweden and Finland), a more local unit, or a political and legal unit. Patriotism in early modern Sweden could thus to some extent be directed towards the inhabitants of this fatherland too. ${ }^{15}$

Nordin eschewed the terms ethnie and ethnicity in favour of the term nation which, according to him, better reflected the case in early modern Sweden. ${ }^{16}$ Gustafsson, on the other hand, uses the term ethnic. According to him, Smith's 'ethnies' should not be confused with nations, as the latter seek political sovereignty and include large segments of the population. ${ }^{17}$ Ethnicity also, like ethnie, describes a perceived cultural community that is maintained by factors such as language, common origins, and religion, but ethnic groups do not have to be separate in an objective sense. ${ }^{18}$ In this respect, I will be using the term ethnic in the present article, rather than national, to determine whether 'ethnic' identities in early modern Sweden were strong enough produce views similar to ethnonational conceptions in modern historiography. I do not presuppose the objective, actual existence of ethnicities. The question is whether or not they were perceived to have existed. ${ }^{19}$ I will therefore use the concept as a tool to analyse scholarly conceptions.

It is clearly necessary to understand views regarding the origins of Swedes in these regions as well, but a focus on the Finns is justified because an ethnic distinction between Swedes and Finns is alleged to have existed in the early modern era by much of presentday Swedish historiography, especially seeing as the 'Gothicist' view - based on notions 
of ancient Swedish greatness - is thought to have peaked during the $17^{\text {th }}$ century, when Sweden was considered a great power. ${ }^{20}$

My sources include syntheses of Nordic history as well as specific historical treatises on the subject - such as the famous Lapponia, a history of Lapland written by Johannes Schefferus in 1673. In practical terms, I will analyse all the extant seventeenthcentury material dealing with the subject, and explain the views found in these sources by contextualising them within a larger historical frame of reference.

I will argue that, while some features of seventeenth-century historical accounts show that attempts were made to emphasise the importance of particular groups over others in northern parts of the realm, 'ethnic' identities were not the most significant factor in historical interpretations. Views on the origins of the Finnish population should also be understood in the context of factors such as shifting historical sources, the lack of criticism surrounding these sources, and patriotism in early modern Sweden. My article will thus contribute to an understanding of the nature of early modern Swedish historiography and the relevance of ethnic identities on historiography.

In the present-day context, this article also contributes to debunking recent pseudo-historical notions emphasising a glorious Finnish 'ethnic' past in Finnish far-right online discussions. These notions have been based on views they argue are presented in $17^{\text {th }}$ century Swedish scholarship, particularly the work of Johannes Messenius, which we turn to next. ${ }^{21}$ This article will show that these Swedish views actually never necessarily had the 'ethnic' basis that the Finnish far right online discussion maintains.

\section{King Dumbr and the Amazons: Johannes Messenius and the Construction of Ostrobothnian Antiquity in the Early $17^{\text {th }}$ Century}

Much of late medieval and early modern Swedish historiography was dominated by the Gothicist view emphasising the greatness of Ancient Sweden. In this paradigm, the 
Swedes were thought to have descended from the Goths of antiquity and have links with the ancient Scythians. The Bible was a source of great historical authority, and a crucial notion in the Gothicist view was that an ancient Swedish settlement had been established not long after the Great Flood. Indeed, Swedes were thought to be descendants of Noah's grandson, Magog. ${ }^{22}$

Johannes Messenius, a notable Swedish historian and professor at the University of Uppsala in the $17^{\text {th }}$ century, was one such scholar operating within the Gothicist framework. Accused of collusion with Catholics, he was sentenced in 1616 to life imprisonment in Kajana (Kajaani) Castle in Ostrobothnia. During his imprisonment, Messenius authored a massive work on the history of Scandinavia, Scondia Illustrata, which remained unpublished until $1705 .^{23}$ The tenth part of Scondia, written in 1628 and 1629 contained a rime chronicle about Finland, Livonia, and Courland, the Finnish part of which he also did a version of in Swedish (1629). ${ }^{24}$

Like many of the Gothicist historians that preceded him, Messenius considered the Great Flood to be the starting point of history. Scandinavia had been settled by the fourth son of Noah, Thuiskon, in the year 193 after the flood. Over a century later, the Baltic shores were then settled by Scandinavian Vandals; while the Finns, whom Messenius considered to be part of a larger community of Venedi (or Vends), were not thought to have reached the Baltic shores until approximately 60 BC. Messenius was, in effect, implying that the Finns had arrived in Finland much later than the Swedes, and that there was thus an 'ethnic' difference between the two groups. The Vends had been mentioned in sources of classical antiquity, and the Gulf of Finland had been called Sinus Venedicus in a sixteenth-century map. ${ }^{25}$

Some of the typical elements used in constructing the Gulf of Bothnia's early history were introduced to Swedish historiography by Messenius. He pioneered the use 
of the Icelandic sagas in this context, ${ }^{26}$ and Fundinn Noregr - part of the Orkneyinga saga - tells the story of King Fornjotr (and his descendants), ${ }^{27}$ Messenius believed that they had ruled over Scandinavia and Kvenland in roughly 600 BC. ${ }^{28}$

According to Messenius, Kvenland was identical to Ostrobothnia. He considered the name Cajana, used to describe Ostrobothnia in many maps of that time, ${ }^{29}$ to be a corrupted form of the term Kvenland. Based on classical sources describing the Amazons, and a chronicle written by Adam of Bremen in the 11th century AD, describing a Terra Feminarum (Land of Women) near Sweden, Messenius took the word 'kven' to literally mean kvinna (woman), so that Kvenland described an ancient realm of warrior women in Ostrobothnia. He considered them to be the wives of descendants of peoples from the land of Swedes (Svea) and Goths. These descendants had given their wives Kvenland to settle at some point during the reign of Fornjotr. ${ }^{30}$

According to Messenius, this land of the Amazons had survived intact until 1053 AD when, according to Adam of Bremen's chronicle, ${ }^{31}$ an army led by Anund (son of the Swedish king, Emund) was poisoned by them. Subsequently, the Swedes waged a war of extermination against the Amazons until they had secured total possession of the area. ${ }^{32}$

At first glance, it seems here that Messenius was making the earliest attempt to specifically associate the Kvens with a perceived Swedish ethnie. Yet a curious passage from the tenth part of Scondia, which described the war waged on the Amazons by the Swedes as against 'other Finns' (Finnonum reliquis), illustrates that this might not actually be the case. ${ }^{33}$

There are two ways of interpreting it; either Messenius considered the Amazons to be Finns, because they lived in the geographical area of Finland, or that the Amazons were at least partly descended from Finns. If the latter interpretation is correct, Finns would have thus been in the region since medieval times. Whether or not this is the case, 
the boundary between Swede and Finn seems to have been much more fluid in Messenius' eyes than the ethnosymbolist model would initially suggest. If he considered the Amazons to have become Finns by simply staying in the geographical area of Finland, his views would suggest an interchangeability and impermanence in the concepts of Finnish and Swedish. As Jens Lerbom has concluded, language did not necessarily play a part in early modern political or cultural conceptions of Swedishness, nor was this Swedishness necessarily fixed. The term 'Finnish' did not necessarily have anything to do with the language in early modern times, either. It could simply refer to an inhabitant of Finland. In scholarly contexts, though, Finns could often be seen as a people with a different language and history. ${ }^{34}$

Messenius introduced another element to Swedish historiography concerning the early history of the Gulf of Bothnia, when he described the Icelandic saga, Bárðar saga Snafellsáss, which told of a King Dumbr living on the shores of Dumbshaff. ${ }^{35}$ In the early 1600s, the Icelandic historian Arngrimus Jonae thought Dumbshaff to be the Gulf of Bothnia, ${ }^{36}$ and Messenius agreed with this, claiming that Dumbr had ruled there in the $9^{\text {th }}$ century AD. ${ }^{37}$ However, Messenius made no attempt to make him either Swedish or Finnish. This indicates that he was not trying to construct a history based on any specific ethnie or its dominance.

According to Colin Kidd, biblical pedigrees for different peoples played a part in early modern British discourse too, but ethnic identities were of secondary importance. These pedigrees pointed to differentiation within a common stock, not to strictly innate differences. Scholars were not seeking to exclude other groups from their constructions of history. ${ }^{38}$

Johanna Widenberg, however, maintains that seventeenth-century Swedish historians who studied material antiquities were not interested in any found in Finland 
before the Swedish conquest in the $12^{\text {th }}$ century. Rather, they interpreted antiquities found in Sweden proper as belonging to a Swedish ethnie that had nothing to do with Finns. ${ }^{39}$ Even if Messenius was focusing more on literary antiquities, such as the Icelandic sagas, his views nonetheless run counter to Widenberg's observations. Messenius was certainly interested in Finland and considered Swedes to have been influential there, but he does not seem to exclude Finns. This implies that Widenberg's results may not have a more general applicability beyond the concept of material antiquities. A purely ethnosymbolist approach, emphasising the dominance of ethnic factors, is out of place here. My interpretation that Messenius saw the terms 'Finnish' and 'Swedish' as being rather fluid, and was reluctant to ethnonationalise elements of Swedish history is supported by the results of researchers such as Colin Kidd and Harald Gustafsson, who also maintain that ethnic identities were not so important in early modern times. This would also explain the similarity between Swedish and British early modern discourses.

Another seventeenth-century version of Ostrobothnian history indicates the relative insignificance of ethnicity: In a speech 1643, Martinus Wargius, a student at the newly established Academy of Åbo (Turku), described his native Ostrobothnia as having once been a part of ancient Scythia and Sarmatia, and thus one of the oldest inhabited regions in the world. ${ }^{40}$ The emphasis here was clearly on the age of the region and its inhabitants rather than the perceived ethnic origins of the people - this was more important.

Messenius' view of Ostrobothnian history contains several elements typical of early seventeenth-century historiography - much of which was based on secondary sources and comparing the works of earlier historians. Although it may have already been acknowledged by the French Renaissance humanists of the $16^{\text {th }}$ century, the 'modern' distinction between primary and secondary sources was still vague - even to many late 
eighteenth-century Swedish historiographers. ${ }^{41}$ The idea of Amazons in Sweden, for instance, was originally based on the work of Johannes Magnus, a sixteenth-century Swedish historian who considered them to have actually been Swedish. ${ }^{42}$ This also highlights another feature of early modern histories, applicable not just to Sweden but elsewhere in Western Europe too - they often appropriated classical sources and made dubious etymological comparisons. ${ }^{43}$

The reliance on older historians, in turn, was based on the dominant mode of thought - Aristotelian scholasticism - which held that the older the source, the more authoritative this generally meant it was. ${ }^{44}$ It was perhaps for this reason that Messenius did not attempt to criticise the 'new' Icelandic sources he was using. This lack of source criticism certainly influenced his views.

\section{Johannes Bureus and the Glorious Birkarl Lineage}

The contentious issue of boundaries and taxation rights in Lapland came to a head between Denmark and Sweden at the turn of the $17^{\text {th }}$ century. The 'Birkarls' were a group living in the northern localities of Torneå (Tornio), Kemi, Luleå and Piteå at this time, who had been granted the right to collect taxes from the Saami. ${ }^{45}$ In 1599 , they gave testimony on how they had gained their rights through warfare and trading the property they had inherited in the parish of Birkala (Pirkkala) and elsewhere in Finland. ${ }^{46}$

The following year, an official at the Swedish Royal Chancellery, Johannes Bureus, travelled to Norrland for the purposes of documenting antiquities. ${ }^{47}$ As part of a collection of notes entitled Sumlen, he reported that the Birkarls had ruled over the Saami in areas as far north as the Arctic coast during the reign of Swedish king, Magnus Ladulås in the late $13^{\text {th }}$ century. ${ }^{48}$

In 1555, however, a Swedish historian and cartographer, Olaus Magnus, had published a different theory concerning the Birkarls. ${ }^{49}$ According to him, the word meant 
'men of the mountains' (viri montium).$^{50}$ Later on, early seventeenth-century authors, such as the cartographer Andreas Bureus ${ }^{51}$ (cousin of Johannes), mentioned the Birkarls without speculating on their origins. ${ }^{52}$

An important early seventeenth-century scholar of antiquities in Sweden, Johannes Bureus was also well versed in the study of the Kabbala and Jewish mysticism. Because his Neoplatonist perspective was based on the notion of there being a hidden world of deeper meaning which would manifest itself through various signs, he spent a considerable amount of time trying to decipher the underlying meanings of letters, words, and runes. ${ }^{53}$

Bureus seems to have had a high opinion of himself: in 1613, while visiting Dalecarlia, he believed he was called upon by God to go forth as a prophet and spread the ancient runic wisdom he had discovered in preparation for the second coming of Christ and the Apocalypse. ${ }^{54} \mathrm{He}$ also believed he had a noble heritage, based on the underlying meanings he had discovered in his own name. ${ }^{55}$

By exchanging any letters in a given word, the Kabbalists would aim to decipher these underlying meanings, ${ }^{56}$ and so it was that, in the early $1600 \mathrm{~s}$, Bureus wrote an introductory summary to the fabulous history of the Bure lineage as part of a wider work on his family tree. ${ }^{57}$

Bureus found a wide variety of correspondences for the prefix Bur- and its cognates in classical sources. ${ }^{58}$ In fact, he found that members of the Bure lineage had been in most European elites in classical times, and that the earliest members had even been a 'godlike' elite among the ancient Swedes. ${ }^{59}$ Bureus also made the word Birkarl a part of his fabulous family lineage. According to him, the Scandinavian B-rune was 'Byrghall' or 'Byrkull', the latter of which meant, among other things, leader of the Bure family. ${ }^{60}$ 
He claimed that some of the Bure family had been forced to flee their original home in the Swedish province of Helsingland, when their king was burnt to death by King Ingiald of Uppsala. They settled Finland, where they built the church of Birkala. By 1328, the Birkarls had expanded their settlement north to the river Ule (Oulujoki), which bordered the realm of Helsingland, and eventually the Birkarls became the masters of Lapland, as the most prominent members of the Bure family had purportedly gained the right to reconquer this region from King Magnus Ladulås. Bureus maintained that King Algot of Sweden, who supposedly lived in the late $6^{\text {th }}$ century AD, had already at this time conquered Lapland for the Swedish Crown. ${ }^{61}$

The description is a curious hodgepodge - based partly on a fairly uncritical reading of secondary sources, partly on etymological speculation, and on at least one primary source from the Middle Ages. Bureus most likely took the story of King Algot from a chronicle written by Johannes Magnus in the mid- $16^{\text {th }}$ century. According to Magnus, Algot had defeated monstrous 'forest satyrs' living near the North Pole. ${ }^{62}$ It is reasonable to assume that he considered the satyrs to represent the Saami. This can be seen as a 'euhemerism' - an interpretive method commonly used in the $17^{\text {th }}$ century whereby mythical occurrences or persons were described as real historical events and characters. ${ }^{63}$ Like many other kings in the chronicle of Johannes Magnus, King Algot was most likely a fabrication. ${ }^{64}$ The tale of King Ingiald (Illråde), on the other hand, was from the Icelandic Ynglinga saga, which Bureus was clearly acquainted with, ${ }^{65}$ and by associating it with the Bure lineage it is clear that he was making something up, as the saga does not mention any Bure. ${ }^{66}$

The one primary source that Bureus refers to, is an agreement from 1328 between the Birkarls and people of Helsingland on settlement rights in the northern part of Helsingland ${ }^{67}$ The use of this medieval document is understandable, as Bureus had been 
tasked with curating medieval documents in the Swedish National Archives. ${ }^{68}$ The information about Magnus Ladulås, however, is clearly from the notes he took on his trip to Norrland in 1600 .

On a more general level, Bureus' views on the Birkarls do not seem to support Johanna Widenberg's research results, which found the opposite - that pre-medieval Finland was of no interest to seventeenth-century antiquarians. However, Bureus clearly interpreted sources referring to Birkarls in a manner that implied they were ethnic Swedes - the Bure family in Finland had originally come from Helsingland in Sweden. Bureus is usually considered to be part of the Gothicist paradigm in Swedish historiography: according to him, the ancient Swedes had possessed primeval wisdom and an ancient theology that was partly expressed in Swedish runes. ${ }^{69}$

As Patrik Hall states, an important part of the Gothicist framework was the elitecentred construction of noble family lineages, which he calls 'genealogical nationalism'. ${ }^{70}$ It is within this framework that Bureus' views should be interpreted. Far from making the Birkarls Swedes per se, he was making them part of his own family tree - the Birkarls had been one of the many elites that members of the Bure family had been part of throughout recorded history. According to Harald Gustafsson and Colin Kidd, ethnic factors were of secondary importance in early modern times. This emphasis, which Bureus placed on his supposedly glorious family lineage would indeed seem to suggest that early modern researchers were not as interested in perceived ethnies as ethnosymbolist researchers, such as Johanna Widenberg, have claimed.

\section{Johannes Schefferus, Johan Hadorph and the Patriotic View of Birkarl Origins}

In the early 1670s, the Lord High Chancellor of Sweden, Magnus Gabriel de la Gardie, requested that the priests of various congregations in Northern Sweden write reports on the history and present state of the region. This was partly because deposits of ore had 
been found in Lapland, and there were plans to introduce Swedish settlements to the region. $^{71}$

It was in these descriptions of Lapland, some of which were written well before the 1670s, that accounts of the Birkarls as Finns first appeared. One of them, written by Olaus Petri Niurenius (vicar of Umeå Parish) sometime before his death in $1645,{ }^{72}$ was clearly based on information gathered from the Saami. Niurenius described how, at around the same time as Jesus Christ was born, a number of families from the Tavastia area (Häme) - more specifically the parishes of Birkala and Rengo (Renko) - had migrated to a place near present-day Vasa (Vaasa) on the Ostrobothnian coast. By gaining many riches, these migrants attracted the envy of their former countrymen in Tavastia who, as a consequence, selected a nobleman, called Matthias Kurk, to pillage the Ostrobothnian migrants, which forced them to flee to Kemi, Torneå and ultimately further north. ${ }^{73}$

A similar account is given in the description by Johannes Torneus as well as within the introduction to a Saami dictionary written by Zacharias Plantinus, the son of Olaus Petri Niurenius. Interestingly, Plantinus also noted that the Birkarls were thought to be descended from the 'noble Bure family', of which he was a member on his mother's side. $^{74}$

The task of synthesising these and other traditions into a critically analysed whole was given to the holder of the Skyttean Professorship of Eloquence and Government at the University of Uppsala, Johannes Schefferus. Originally from Strassburg, Schefferus was one of the most renowned Swedish historians of the time. In 1671, De la Gardie had already approached the recently founded College of Antiquities (1667) with a request to write a description of the Saami. Schefferus, a member of the College, published the description of Lapland, Lapponia, two years later. Translated into many European 
languages, the work was arguably one of the greatest success stories in seventeenthcentury Swedish historiography. ${ }^{75}$

As Schefferus himself never actually visited Lapland, Lapponia was based on secondary sources, ${ }^{76}$ which he subjected to some degree of critical evaluation. Wellversed in philological methods, he attempted to analyse his sources from a linguistic perspective and compare the views contained therein both logically and systematically. ${ }^{77}$

One crucial point made by Schefferus in his depiction of Saami history was the apparent recentness of traditions presented in a wide range of clerical descriptions. Based among others on ethnographical features, such as the supposed similarity in appearance between Finns and Saami, he accepted the view that these two peoples had common origins, separate from Swedes. According to Schefferus, these traditions only referred to the latest wave of migration. He claimed that the term 'Lapp' was not known until the Danish historian, Saxo Grammaticus, wrote about it in the $13^{\text {th }}$ century. However, both Saxo and certain Icelandic sagas had also mentioned Finnmark and the Bjarmian realm on the shores of the White Sea, and were reminiscent of previous Finnish migrations into Northern Fennoscandia, some of which, triggered by general Slavic movements into the North, happened as early as the $6^{\text {th }}$ century AD. ${ }^{78}$

According to Schefferus, the most recent migration, as depicted in the traditions collected by Northern Swedish priests, occurred after Eric IX had introduced Christianity and Swedish rule to Finland in the $12^{\text {th }}$ century. Lapps fled north to avoid Eric's rule, and Schefferus took the term 'Lapp' to mean 'runaway'. He also based his views regarding the origins of the Birkarls on the tradition found in Bureus' Sumlen, which claimed that the Birkarls emerged during the reign of Magnus Ladulås in the late $13^{\text {th }}$ century, rather than as Niurenius had claimed during the time of Christ. Schefferus also used the same medieval document from 1328 that Bureus had used. ${ }^{79}$ 
Though there are similarities between the Saami tradition and the views presented at the turn of the $17^{\text {th }}$ century, such as the idea that the Birkarls came from Birkala, Bureus did not necessarily know the additional details found in the clerical descriptions. Both Bureus and Schefferus used mostly secondary sources. Schefferus, however, used his sources critically, contextualising and comparing the contents with information found in other secondary sources, such as the work of Saxo.

Another obvious difference concerns the perceived ethnicity of the early Birkarl settlers. Although the boundary between Saami and Finns was rather fluid in Lapponia, Schefferus introduced the idea to Swedish historiography that there was a migration of Western Finns northwards. Different views on Gothicism came into play here too. As already noted by many historians of ideas, Schefferus was critical of the contemporary Gothicist paradigm in Swedish historiography. ${ }^{80}$

Schefferus - being of German origin ${ }^{81}$ - did not construct a view of history in which his own perceived ethnicity played a part, so he had no need to make the Birkarls part of a noble Bure lineage, or even 'ethnic' Swedes for that matter. There is also nothing to suggest that he knew of Bureus' views, except for the fact that they were alluded to in Zacharias Plantinus' introduction to the Saami dictionary (of which Schefferus was aware). What does seem to be of far more importance was that the Birkarls - as Swedish subjects - had been the first to subjugate the Lapps in Fennoscandia. ${ }^{82}$

Though it has been stated elsewhere that there is no plausible proof of a connection between Schefferus' work and the Swedish decree of 1673 concerning settlements in Lapland, ${ }^{83}$ there is a tendency to emphasise old Swedish rights over the territory in Lapponia, ${ }^{84}$ and it is within this context that Schefferus should be interpreted. He was a patriot in the early modern sense - that is his loyalty was to the Swedish Crown, ${ }^{85}$ rather than any purported Swedish or Finnish ethnie with a glorious past. 
Nevertheless, it would be inappropriate to construct a false dichotomy between the patriotic views of Schefferus and Bureus. This becomes especially apparent when we consider another important figure at the College of Antiquities, Johan Hadorph, who was working as an academy secretary at the University of Uppsala. Although he never subscribed to the more radical views of Olof Rudbeck the Elder, he did operate firmly within the Gothicist paradigm. ${ }^{86}$

Old Swedish legal documents, regarding provincial laws, for instance, were an important part of the collection of antiquities. This was partly due to the need to justify ancient Swedish rights to newly acquired provinces in the Swedish realm. ${ }^{87}$ In 1676 , Hadorph published the Law of Dalecarlia, in the preface of which he briefly described old Swedish municipal rights - or more specifically the Birke or 'town' law. Once again, etymological comparisons came to the fore. Hadorph considered the Birkarls (Birkekarlar, in Western Norrland - Luleå, Piteå and Torneå) to have been traders, as birk was an ancient Swedish word for trade. ${ }^{88}$

Although his views seemingly contradict the notions of Birkarl origins presented just a few years earlier in Lapponia, Hadorph did not criticise Schefferus, nor did he construct an intricate alternate theory on the origins of these traders. His views represent a shift away from areas east of the Gulf of Bothnia - Ostrobothnia did not factor into the equation - the supposed origin of the word Birk focused instead on the core areas of Sweden. However, he did not claim that the Birkarls represented any specific ethnicity; the Gothicist paradigm in Swedish historiography therefore did not necessarily imply that the Birkarls were part of an ethnic Swedish history, indicating that a strictly ethnosymbolist interpretation of his views would be inappropriate. In my view, the relative, if not complete insignificance of these purported ethnic identities when interpreting history seems to hold true as much for Hadorph as it did for Schefferus. 


\section{Olof Rudbeck, Daniel Juslenius, and the Fabulous Construction of Northern}

\section{Antiquity}

Olof Rudbeck the Elder is arguably one of the most famous figures in Swedish intellectual history. A professor of medicine at the University of Uppsala, Rudbeck is credited with having made important discoveries about the lymphatic system. Yet his most significant claim to fame is perhaps his four-part book on early Swedish history published between 1679 and 1702 - the Atlantica. ${ }^{89}$ The central thesis throughout almost the whole of its 2000 pages concerns the ancient Swedish origin of all human civilisation. ${ }^{90}$

According to an oft-cited anecdote, Johannes Schefferus supposedly read a part of the Atlantica on his deathbed and stated that there 'was also a lot of madness in it', ${ }^{91}$ yet there was a method in his madness, at least according to historians of science and ideas who analysed him hundreds of years later. In attempting to prove the Swedish origins of kings, places and phenomena found in classical sources, he employed etymological and euhemeristic methods widely used at the time. Rudbeck claimed that ancient myths had a real and concrete historical background and a Swedish origin which classical Greek writers, for instance, had been unable to understand. According to Rudbeck, the ancients had expressed themselves in riddles which had to be interpreted. Environment, topography and natural science also played a role. A natural scientist by trade and aware of new Cartesian and Baconian conceptions of experimentation and observation, Rudbeck frequently made scientific experiments to prove his points on Swedish history. ${ }^{92}$

Rudbeck's views have been extensively analysed in both Swedish and Finnish research.${ }^{93}$ I will provide a few examples of his construction of the history of areas in the north of the Swedish realm and present a somewhat larger context for his views on Finns than has been given in previous research. 
Much like his Gothicist predecessors had done, Rudbeck described a postdiluvial Swedish settlement in Atlantica. After the Great Flood, the Swedes led by Magog, the grandson of Noah, settled the Bothnian shores before proceeding to inhabit the regions around Uppsala which, according to Rudbeck, was the site of the ancient Atlantis. Here the Swedes flourished and went on to conquer most of the known world. ${ }^{94}$

One interesting example of the significant role of Ostrobothnia comes from the first part of Atlantica, where Rudbeck wanted to prove the Northern origins of the 'Cimmeria' mentioned in ancient Greek sources, which he believed described the Ostrobothnian region of Kemi and the adjoining areas of Lapland. Etymological comparisons were only a part of his reasoning, however; the ancient Greeks had also described the Cimmerians as living in near-perpetual darkness, which he interpreted as clearly indicating the particular boreal region of Kemi, as this was a place where the sun would not appear for long periods of time in the winter. In addition, he attempted to prove in geographical terms that information concerning the location of the Cimbri people in classical sources could also be traced to the boreal north. ${ }^{95}$ Rudbeck thus combined etymology, topography, scientific observation, and euhemerisms to argue his case.

A crucial part of Atlantica is Rudbeck's notion that worshipping the sun, moon, and earth was Swedish in origin, and had also begun near Ostrobothnian Kemi, ${ }^{96}$ as had the cult of the goddess Isis. According to Rudbeck's typical euhemeristic, topographical and etymological ruminations, Isis (Io) was a real historical figure and Ostrobothnia, along with Lapland, was the domain of her father Jonaker, who was mentioned in Icelandic sagas and also known also as the legendary King Inachus. According to Rudbeck's genealogical calculations, Inachus had lived in and around the year 1870 after Creation $(2130 \mathrm{BC}){ }^{97}$. Traces of these historical figures remained in the area, in the form of Jovara - the mountain of Isis (undoubtedly Iivaara in Kuusamo), Jo flod (Iijoki), and 
Lake Enare (Inari). According to Rudbeck, Isis had introduced worshipping the Earth to Greeks and Egyptians among others; and with the right interpretation, proof of her travels to these more southern locations could be found in sources such as Prometheus Bound by the Greek playwright Aeschylus. ${ }^{98}$

Proving the Swedish origin of these kinds of cults was of particular importance to Rudbeck, as they also proved the Swedish origin of astronomy and time reckoning. ${ }^{99}$ The Hyperborean myth was a common trope within Gothicism and it clearly played an important part in Atlantica. This myth maintained that that the northern Hyperboreans depicted in classical sources had actually been Swedish and central to the creation of human civilisation. ${ }^{100}$ Indeed, Rudbeck identified Jonaker's realm with the Jaemi, a people related to Swedish Scythians. ${ }^{101}$ As Messenius before him, Rudbeck considered the Finns to have arrived later in the region, as descendants of Mesek - yet another grandson of Noah, ${ }^{102}$ implying the existence of Finnish and Swedish ethnies within the biblical frame of reference.

However, Rudbeck's view of Northern Finnish history did not exclude the Finns, as an important part of the Atlantica concerns the myth of the Amazons. Rudbeck maintained that these women were responsible for ending the Golden Age of Swedish history in roughly the year 2100 after Creation (1900 BC). They had fought the Swedish King Thor (Jofur) and lost, but they then participated in future conquests, under the supervision of Thor, in Asia and Egypt. ${ }^{103}$ Rudbeck believed the realm of the Amazons to be situated mostly in Ostrobothnia. This view was based on, among others, the description of Adam of Bremen. Rudbeck also took the name Kvenland to refer to women. However, it should be noted that, unlike in Messenius' Scondia, Kvenland was not exclusively associated with Ostrobothnia in Atlantica. Rudbeck also found names in southern parts of Finland which could be linked to Amazon leaders. ${ }^{104}$ 
Rudbeck once again tried to link classical authors who mentioned the Amazons such as Diodorus Siculus and the Phoenician Hanno - with northern sources, such as the Icelandic sagas, which depicted strong Swedish women. ${ }^{105}$ Rudbeck noted the different types of women described in classical sources, and compared these with the broad-faced female warriors also found in certain Icelandic sagas. Rudbeck claimed that these could have described Finns, who were generally round-faced. In addition to the Swedish 'Scythian' Amazons, he maintained that there had been darker Finnish or Saami Amazons, ${ }^{106}$ as well as another group of Amazons related to the Gorgons mentioned in classical literature. He located the latter in Karelia, but his description of their origins was quite vague..$^{107}$

As Gunnar Eriksson has noted, physical geography played an important part in Rudbeck's affection for his native 'fatherland', rather than the mysticism related to blood ties or tribal connections - he did not even view the Saami necessarily as a different people. ${ }^{108}$ It is interesting, too, that neither Messenius or Rudbeck excluded the Finns from their concept of the Amazons. It is reasonable to conclude that both were writing their historical versions of the Swedish Realm - not just as a political concept but also one with certain ethnoterritorial connotations; in historical terms, this meant that the area did not include just a single 'ethnic' group. Indeed, it seems unlikely that Rudbeck would have gone so far as including Finns as Amazons, had his intention been simply to glorify a perceived Swedish ethnie - there was clearly ample room for other groups.

It seems Rudbeck was well aware of how his version of events might have been misinterpreted. In the second tome of Atlantica, he protested against those who claimed he was doing all of this just to glorify his 'fatherland' (Fädernesland) ${ }^{109}$ The emphasis on the term fatherland, rather than particular groups such as Swedes or Goths, is telling. In terms of the geographical focus of Atlantica, the fatherland probably meant Sweden 
and Finland. The argument presented in this article on the lesser importance of purported ethnic identities in early modern times thus also holds true for Rudbeck. It is also supported by the views of Harald Gustafsson and Colin Kidd. ${ }^{110}$

Views of a fabulous antiquity were constructed in Finland as well; at the end of Sweden's era as a great power (at the turn of the $18^{\text {th }}$ century), Daniel Juslenius wrote two important works on Finnish prehistory - Aboa vetus et nova (Old and New Åbo) in 1700, and Vindiciae Fennorum (Defence of the Finns) in 1703. Interpreted within the ethnosymbolist framework, these books are considered to be some of the earliest manifestations of Finnish nationalism. According to the Finnish historian of ideas, Juha Manninen, Juslenius' perception of Finland as a nation was not so much based on language, but rather on geography - as part of a larger Swedish fatherland. According to Manninen, Juslenius' proto-nationalism emerged during the early phases of Charles XII's conquests. At this time, it became necessary to provide assurances of Finnish fidelity to the Swedish Crown and examples of Finnish military prowess. ${ }^{111}$

However, there are grounds for a more radical interpretation of Juslenius' work than Manninen's analysis would suggest. At the beginning of the historical part of Aboa vetus et nova, Juslenius clearly defines the historical Finns in terms of the Finnish language. However, this is muddled by the fact that Juslenius considered both Finns and Swedes to be descendants of the Scythians, ${ }^{112}$ and therefore more closely related to each other than other scholars, such as Rudbeck, had maintained. This indicates that the ethnosymbolist argument is at least in part problematic, as the boundary between these alleged ethnies is fluid. This is also consistent with Kidd's views on biblical pedigrees not pointing to innate differences. ${ }^{113}$

Juslenius was trying to construct an old and glorious Finnish culture as part of a biblical and Gothicist history in Aboa vetus et nova. ${ }^{114}$ Juslenius referred to the Amazon 
realm of Kvenland as an expression of the military prowess of Finnish women, but this realm represented the totality of Finland, not just Ostrobothnia. ${ }^{115}$

In the spirit of Rudbeck's euhemeristic and topographical claims, Juslenius identified Cimmeria to be in the environs of Kemi. An inaccurate translation from the original Latin into Finnish and Swedish in the 2005 publication of Aboa vetus et nova would certainly suggest that Juslenius considered Cimmerians to be exclusively ethnic Finns. The original Latin, however, states that the inhabitants of Kemi are a part of Finland (hos partem Finniae nostrae constituere), while the Finnish and Swedish translations indicate more directly that these inhabitants are Finns (kemiläiset ovat suomalaisia/kimiläiset är finnar). In other words, the translation refers to the people, whereas Juslenius' original was more likely referring to the geographical concept of Finland. Juslenius considered both Finns and Goths to be descendants of the Cimmerians who had invented the alphabet. ${ }^{116}$

Juslenius, unlike Rudbeck, thus included Finns in his conceptions of the Cimmerians. At the same time, Ancient Swedes were an integral part of Ostrobothnian antiquity. Once again, it does not seem that historians were writing histories of single ethnies or attempting to exclude other groups living in the region. This again would seem to indicate the lesser importance of ethnicity to early modern interpretations of history, as with the other scholars analysed in this article.

\section{Concluding Discussion}

In seventeenth-century Swedish historiography, there were two main ways of looking at the early history of the realm's northern parts and the role of Finns there. The first, concerning a postdiluvial settlement along the Baltic coastline thousands of years ago, was quite vague in its details. The Finns, thought to have been living in the area for at least two millennia, were nonetheless considered to have arrived in the area after the 
Swedes. Both Johannes Messenius and Olof Rudbeck the Elder included Finns in their concept of the Amazons and claimed that a realm of female warriors inhabited Kvenland in Ostrobothnia; yet it is unclear whether Messenius considered the Amazons to be of a perceived Finnish ethnie, or if he was simply using the term 'Finnish' in a geographical sense. Daniel Juslenius, too, included Finns in his conceptualisation of Cimmeria and as part of the fabulous construction of Finnish history.

The second major view, concerning the origin of the Birkarl tax collectors, was more focused. According to views presented by the Birkarls themselves at the turn of the $17^{\text {th }}$ century, they had originated from the Finnish parish of Birkala. Johannes Bureus associated them with his own family, which was of Swedish origin. Johannes Schefferus, on the other hand, considered them to be of Tavastian (Finnish) descent, based on traditions collected by the clergy in Northern Sweden. Birkarls had reached the northern parts of the Gulf of Bothnia in the late $13^{\text {th }}$ century. Johan Hadorph associated the Birkarls with the ancient Swedish word for trade, Birk, but he did not engage in further speculation on their origins.

The emergence of these views is clear from a purely mechanical perspective. As mentioned above, the Bible was a source of great historical authority, and a crucial notion in the Gothicist view was that an ancient Swedish settlement had been established not long after the Great Flood. In addition, Gothicist historians attempted to associate people and events depicted in sources of classical antiquity with Swedish history using etymological comparisons (e.g., the Amazons). This tendency reached spectacular heights in Rudbeck's Atlantica, where practically all classical sources were interpreted as sources of Swedish history using euhemerisms, etymological comparisons and, as a novelty, methods of natural science. 
There was clearly a tendency in seventeenth-century Swedish historiography to use the views of earlier historians and, as such, many conceptions were based on what we would now call secondary source material. Previously unknown and unused sources nevertheless emerged throughout the $17^{\text {th }}$ century, such as the Icelandic sagas - which became an important factor in the historical construction of Kvenland, and traditions collected in the early $17^{\text {th }}$ century - which led to new theories concerning the Birkarls. Yet many of these 'new' sources were accepted without criticism. Perhaps the most comprehensive attempt to analyse sources was made by Johannes Schefferus. He placed the various traditions surrounding Birkarl origins in what he thought was their proper context using the work of medieval historians, such as Saxo Grammaticus.

There has been a tendency in certain strains of Swedish and Finnish historiography to claim the existence of ethnic or national identities in early modern Sweden. These claims do have some merit. Throughout this article, I have shown that Swedish historians operating within the Gothicist framework emphasised the role of ethnic Swedes and Goths in the construction of histories concerning the northern parts of the Swedish realm. Yet there are some significant issues to address within the ethnosymbolist model. For example, the boundary between Swede and Finn is somewhat nebulous in the cases of Messenius and Juslenius, suggesting that the concept of ethnie might not even be relevant to begin with. Biblical differences in ethnie might not be seen as innate, as researchers such as Colin Kidd have argued in the early modern British context. Furthermore, a consistent theme in the construction of the region's history is the willingness of Swedish historians to give Finns a prominent role in it. But one should also point out that historians were also, in some cases, reluctant to associate people in the region with either Swedes or Finns. 
Swedish historians were evidently interested in Ancient Finland - including Ostrobothnia. Some of them associated Swedes with the region, but they usually gave Finns a role as well. These observations are inconsistent with Johanna Widenberg's research results, indicating that the purported lack of interest in Finland in the interpretation of material antiquities and their exclusive association with ethnic Swedes might not have extended as far as the interpretation of literary sources. I would suggest that this highlights a common problem with the ethnosymbolist model - a tendency to overestimate the role of early modern national or ethnic identities when other factors may have actually been more important. Johannes Schefferus constructed a fundamentally patriotic view of the ancient influence of the Birkarls. The concept of 'fatherland' also seems to have been important in Rudbeck's conceptions, while Johannes Bureus went so far as to emphasise the role of yet another element - his own family. Ethnic identities might certainly have existed in Sweden, but they were not of paramount importance. In this respect, the results presented in this article are supported by views presented by other researchers such as Colin Kidd and Harald Gustafsson on early modern ethnic identities in Britain and Sweden.

The ethnonationalising tendencies described by Teemu Ryymin and Per Pippin Aspaas belong to a much later phase - the development of nationalism in the $19^{\text {th }}$ century. Earlier historians did not necessarily attempt to exclude Finns from the Gulf of Bothnia's early history. Overestimating the importance of ethnic identities in early modern times thus reeks distinctly of anachronism.

\section{Funding}

This work was supported by the Finnish Cultural Foundation (Grant no. 00180988). 


\section{Notes}

${ }^{1}$ Blomstedt, Laati and Havu, Kuka kukin oli, 15.

${ }^{2}$ Ahmavaara, Piirteitä Iin pitäjän historiasta, 8, 20-35.

${ }^{3}$ For a brief overview of the conceptions surrounding the Kvens, see Julku, KvenlandKainuunmaa, 11-39.

${ }^{4}$ Ryymin and Aspaas, "Kvenbegrepet," 59-63.

${ }^{5}$ From our point of view, the time periods in question could be characterised as 'prehistoric' and 'medieval'.

${ }^{6}$ The administrative status of these provinces varied during the $1600 \mathrm{~s}$. In the mid- $17^{\text {th }}$ century, for instance, these provinces were briefly united to form the county of Westro- and Ostrobothnia, stretching northwards from Vaasa and Umeå. The border between the provinces usually left the Torne river valley on the Westrobothnian side. See Wikström, Norrbotten, 45-61.

${ }^{7}$ Krook, ”Österbottens ställning," 36-38; Eng, Det svenska väldet, 365-372.

${ }^{8}$ Smith, Myths and Memories, 12-17.

${ }^{9}$ Lerbom, Svenskhetens tidigmoderna gränser, 10-11.

${ }^{10}$ Nordin, Ett fattigt, 429-454.

${ }^{11}$ Antiquarian research usually covers a wide variety of source material, such as ancient laws, documents and ruins. These can be collectively referred to as 'antiquities'. Anttila, The Power of Antiquity, 21.

${ }^{12}$ Widenberg, Fäderneslandets antikviteter, 18, 232-250.

${ }^{13}$ Nurmiainen, "Frågan om 'etnisk nationalism,"” 264-275.

${ }^{14}$ Gustafsson, "The Eighth Argument," 107-113.

${ }^{15}$ Lindberg, Den antika skevheten, 116-121, 128-129, 142-150; Legnér, Fäderneslandets rätta beskrivning, 12.

${ }^{16}$ Nordin, Ett fattigt, 21-24.

${ }^{17}$ Gustafsson, "The Eighth Argument," 91-95.

${ }^{18}$ Lerbom, Svenskhetens tidigmoderna gränser, 23-24.

${ }^{19}$ Cf. Gustafsson, "The Eighth Argument," 93.

${ }^{20}$ Cf. Urpilainen, Algot Scarin, 33-40.

${ }^{21}$ Aalto and Hihnala, "'Saagat tuntevat Suomen kuninkaat," passim.

${ }^{22}$ For a general overview, see Jensen, Forntid i historien, 35-59.

${ }^{23}$ Schück, "Johannes Messenius (1579/80-1636)," 96-99, 102; Lehtinen, Suomen varhaishistorian, 75-76. 
${ }^{24}$ Lönnroth and Linna, "Esipuhe," 7; Olsson, Johannes Messenius Scondia Illustrata, 92-93, 96-97.

${ }^{25}$ Messenius, Scondia X, 1-2; For an overview of Messenius' conceptions, see Lehtinen, Suomen varhaishistorian, 83-87.

${ }^{26}$ On Messenius and Icelandic sagas, see Wallette, Sagans svenskar, 87.

${ }^{27}$ Orkeyinga Saga, 23-34.

${ }^{28}$ Messenius, Scondia X, 1.

${ }^{29}$ Julku, Kvenland - Kainuunmaa, 100-119.

${ }^{30}$ Messenius, Scondiae XIII, 16; Messenius, Scondia X, 1-2, 4; Messenius, Scondiae XI, 22; Messenius, "Finlands rimkrönika," 164. On the general background of this description, see Lehtinen, Suomen varhaishistorian, 84-85.

${ }^{31}$ Lehtinen, Suomen varhaishistorian, 91.

${ }^{32}$ Messenius, Scondia X, 4.

${ }^{33}$ Messenius, Scondia X, 4.

${ }^{34}$ Lerbom, Svenskhetens tidigmoderna gränser, 183-184; Villstrand, Finlands svenska historia $2,53-64,241-245$.

35 "Bård Snäfellsasens saga," 72-73.

${ }^{36}$ Jonae, Crymogaea, 113-114.

${ }^{37}$ Messenius, Scondia X, 4.

${ }^{38}$ Kidd, British Identities before Nationalism, 287-291.

${ }^{39}$ Widenberg, Fäderneslandets antikviteter, 222-224, 233-247.

${ }^{40}$ Wargius, Commendatio (No page numbers are present). For more on the context for this speech, see Lehtinen, Suomen varhaishistorian, 144-145.

${ }^{41}$ On early modern historiography, see Urpilainen, Algot Scarin, 101, 109, 133; Torstendahl, Källkritik och vetenskapssyn, 6-14; Grafton, What was History?, 68.

${ }^{42}$ Nordström, Johannes Magnus, 149-158.

${ }^{43}$ Cf. Anttila, The Power of Antiquity, 22-25, 56, 70.

${ }^{44}$ Jensen, Forntid i historien, 58, 114-115, 259.

${ }^{45}$ Johnsen, Finmarkens politiske historie, 36-78, 104-128.

${ }^{46}$ The testimony is printed in Johnsen, Finmarkens politiske historie, 267-268.

${ }^{47}$ Norris, Pilgrimage, 154-155; Steckzén, Birkarlar och lappar, 82-86.

${ }^{48}$ Bureus, Sumlen, 180.

${ }^{49}$ On Olaus Magnus, see Lindroth, Svensk lärdomshistoria: Medeltiden, reformationstiden, 296-309. 
${ }^{50}$ Magnus, Historia de gentibus septentrionalibus, 137.

${ }^{51}$ On Bureus, see Lindroth, Svensk lärdomshistoria: Stormaktstiden, 481-484.

${ }^{52}$ Bureus, Orbis Arctoi (The book does not have numbered pages).

${ }^{53}$ Jensen, Forntid i historien, 62-64, 91-93; Lindroth, Svensk lärdomshistoria: Stormaktstiden, 152-161, 237-242; Anttila, The Power of Antiquity, 54-75; Norris, Pilgrimage, 92-94, $340-344$.

${ }^{54}$ Norris, Pilgrimage, 10-11, 398-399.

${ }^{55}$ Sikeborg, "Baggars söner och halvgudar," 1, 19, 32-35; Anttila, The Power of Antiquity, 7475.

${ }^{56}$ Sikeborg, "Baggars söner och halvgudar," 19

${ }^{57}$ Sikeborg, "Om versionerna," 1-5.

${ }^{58}$ Bureus, "Bura Namn," 15-23.

${ }^{59}$ For an overview, see Sikeborg, "Baggars söner och halvgudar," 88-95.

${ }^{60}$ Sikeborg, "Baggars söner och halvgudar," 36-40.

${ }^{61}$ Bureus, "Bura Namn," 37.

${ }^{62}$ Magnus, Goternas och svearnas historia, 260.

${ }^{63}$ On euhemerisms, see Anttila, The Power of Antiquity, 71.

${ }^{64}$ Löw, Sveriges forntid, 83-85.

${ }^{65}$ On Bureus and the Ynglingatal, see Wallette, Sagans svenskar, 86.

${ }^{66}$ Sturluson, "Ynglinga-sagan," 41-47.

${ }^{67}$ This document is printed in Finlands medeltidsurkunder I (DF 360). Cf. Bureus, "Bura Namn," 37, note 246.

${ }^{68}$ Lindroth, Svensk lärdomshistoria: Stormaktstiden, 243.

${ }^{69}$ On Bureus and Gothicism, see Anttila, The Power of Antiquity, 49-75; Norris, Pilgrimage, 248-249, 287-319, 480-492.

${ }^{70}$ Hall, Den svenskaste historien, 26-28, 31, 40.

${ }^{71}$ Löw, "Johannes Schefferus," 9-14; Lindroth, Svensk lärdomshistoria: Stormaktstiden, 317318; Sörlin, Framtidslandet, 27-34.

${ }^{72}$ Wiklund, "Förord," 3-4.

${ }^{73}$ Niurenius, "Lappland," 7-9.

${ }^{74}$ Torneus, "Berättelse om Lapmarckerna," 17-18; Setälä, “Ein Lappisches Wörterverzeichnis," 86-89. 
${ }^{75}$ Löw, "Johannes Schefferus," 9-14, 18-23; Ekedahl, "Johannes Schefferus (1621-1679)," 103-112; Lindroth, Svensk lärdomshistoria: Stormaktstiden, 235-237, 242-249, 311, $317-321$.

${ }^{76}$ Löw, “Johannes Schefferus,” 14-18; Lindroth, Svensk lärdomshistoria: Stormaktstiden, 318320.

${ }^{77}$ Ekedahl, "Johannes Schefferus (1621-1679)," 106-107; Lindroth, Svensk lärdomshistoria: Stormaktstiden, 311; Ellenius, "Johannes Schefferus," 65-66.

${ }^{78}$ Schefferus, Lapponia, 42-56.

${ }^{79}$ Schefferus, Lapponia, 50-56, 155-157.

${ }^{80}$ Lindroth, Svensk lärdomshistoria: Stormaktstiden, 311-315; Anttila, The Power of Antiquity, 130-140.

${ }^{81}$ Lindroth, Svensk lärdomshistoria: Stormaktstiden, 311.

${ }^{82}$ Schefferus, Lapponia, 47, 153-154.

${ }^{83}$ Löw, “Johannes Schefferus,” 12.

${ }^{84}$ Cf. Steckzén, Birkarlar och lappar, 99, 102.

${ }^{85}$ See Anttila, The Power of Antiquity, 138; Lindroth, Svensk lärdomshistoria: Stormaktstiden, 311.

${ }^{86}$ Lindroth, Svensk lärdomshistoria: Stormaktstiden, 320-327; Liedgren, "Hadorph, Johan," 697-701.

${ }^{87}$ Schück, Johan Hadorph: Minnesteckning, 239-245; Bennich-Björkman, Författaren $i$ ämbetet, 153, 164-167, 178-180; Widenberg, Fäderneslandets antikviteter, 174-183.

${ }^{88}$ Hadorph, Dahle Laghen, preface.

${ }^{89}$ The fourth part was incomplete. The book was most recently printed in 1950.

${ }^{90}$ For a recent brief overview of the Atlantica, see Anttila, The Power of Antiquity, 143-147; for more on Rudbeck in general, see Eriksson, Rudbeck 1630-1702, passim; Eriksson, The Atlantic Vision, passim.

${ }^{91}$ Lindroth, Svensk lärdomshistoria: Stormaktstiden, 299; Eriksson, Rudbeck 1630-1702, 341.

${ }^{92}$ For an overview on these, see Anttila, The Power of Antiquity, 143-158, 162-164; Eriksson, Rudbeck 1630-1702, 282-284, 497-518, 524-535, 543-560; Anttila, "East of Atlantis," 43-45.

${ }^{93}$ Anttila, The Power of Antiquity, 143-170; Eriksson, Rudbeck 1630-1702, passim; Anttila, "East of Atlantis," passim; Lehtinen, Suomen varhaishistorian, 105-113.

${ }^{94}$ For a brief summary, see Eriksson, Rudbeck 1630-1702, 257-277; Anttila, "East of Atlantis," 43, 47-56; Lehtinen, Suomen varhaishistorian, 105-113. 
${ }^{95}$ Rudbeck, Atlantica I, 326-332.

${ }^{96}$ Eriksson, Rudbeck 1630-1702, 357-358.

${ }^{97}$ Rudbeck, Atlantica IV, 20. According to Rudbeck, the world was created in 4000 BC. See Rudbeck, Atlantica I, 77.

${ }^{98}$ Rudbeck, Atlantica II, 172-173, 226, 405, 489-492, 497, 569-577.

${ }^{99}$ Eriksson, The Atlantic Vision, 107-108.

${ }^{100}$ Anttila, The Power of Antiquity, 29-32, 143-144 and passim.

${ }^{101}$ Rudbeck, Atlantica II, 569. On the association between Swedes and Scythians, see Rudbeck, Atlantica I, 265-279.

${ }^{102}$ Lehtinen, Suomen varhaishistorian, 110-113; Anttila, "East of Atlantis," 51-52; Urpilainen, Algot Scarin, 178-179.

${ }^{103}$ For a brief summary on the Amazons in general, see Lehtinen, Suomen varhaishistorian, 108-110; Eriksson, Rudbeck 1630-1702, 467-474; Anttila, Pohjoiset amatsonit, 25-27.

${ }^{104}$ Rudbeck, Atlantica III, 501-502, 646.

${ }^{105}$ Anttila, Pohjoiset amatsonit, 28-29, 35-36, 54-66; See also Eriksson, Rudbeck 1630-1702, 472-474.

${ }^{106}$ Rudbeck, Atlantica III, 585-593.

${ }^{107}$ Rudbeck, Atlantica III, 584-585; See Anttila, Pohjoiset amatsonit, 29-31, 48-51; Anttila, "East of Atlantis," 54.

${ }^{108}$ Eriksson, Rudbeck 1630-1702, 458, 597-598; Cf. Wallette, Sagans svenskar, 160, 211.

${ }^{109}$ Rudbeck, Atlantica II, 137.

${ }^{110}$ Cf. Gustafsson, “The Eighth Argument,” 94, 109-113. On Rudbeck in light of Kidd's research, see Wallette, Sagans svenskar, 157-167.

${ }^{111}$ Manninen, "Den finska nationen," 233-243; Manninen, Valistus ja kansallinen identiteetti, 76-90; Cf. Fewster, Visions of Past Glory, 52-56.

112 Juslenius, Aboa vetus et nova, 44, 142. To be clear, I am referring to the original Latin text.

${ }^{113}$ Cf. Kidd, British Identities before Nationalism, 287-291.

${ }^{114}$ Fewster, Visions of Past Glory, 52-56.

115 Juslenius, Aboa vetus et nova, 112-114.

${ }^{116}$ Juslenius, Aboa vetus et nova, 140-143. 


\section{Bibliography}

Aalto, Sirpa, and Harri Hihnala. "'Saagat tuntevat Suomen kuninkaat': pseudohistoriallisesta kirjoittelusta Suomen muinaisuudesta”. J@ rgonia 15, no. 29 (2017): 1-30.

Ahmavaara, Arvi. Piirteitä Iin pitäjän historiasta ennen v. 1600. Oulu: Kaleva, 1910. Anttila, Tero. "East of Atlantis: Ancient Finland and its Inhabitants in Olof Rudbeck the Elder's (1630-1702) Atlantica". In On the Eastern Edge of the Baltic Sea: II: Borders and Integration in the History of the Fenno-Baltic Region, edited by Kari Alenius, Anita Honkala, and Sinikka Wunsch, 39-56. Rovaniemi: PohjoisSuomen Historiallinen Yhdistys, 2009.

Anttila, Tero. Pohjoiset amatsonit: Olof Rudbeckin (1630-1702) käsitys amatsoneista Atlantica-teoksessa. MA thesis. Oulu: University of Oulu, 2006.

Anttila, Tero. The Power of Antiquity: The Hyperborean Research Tradition in Early Modern Swedish Research on National Antiquity. PhD diss. Oulu: University of Oulu, 2014.

Bennich-Björkman, Bo. Författaren i ämbetet: Studier i funktion och organisation av författarämbeten vid svenska hovet och kansliet 1550-1850. PhD diss. Uppsala: Svenska Bokförlaget, 1970.

Blomstedt, Yrjö, Iisakki Laati, and Yrjö Havu, eds. Kuka kukin oli: Henkilötietoja 1900-luvulla kuolleista julkisuuden suomalaisista. Helsinki: Otava, 1961.

Bureus, Andreas. Orbis Arctoi: Imprimisque Regni Sveciae Nova \& accurata descriptio. Wittenberg: Christian Tham, 1631.

Bureus, Johannes. “Om Bura Namn och Ätt: Johan Bures inledande avhandling till släktboken”. In Johan Bures släktbok, edited by Urban Sikeborg. Solna: Genealogiska föreningen, 2014 [Electronic version].

Bureus, Johannes. Sumlen: där uthi ähro åtskillighe collectaneer, som uthi een och annan måtta tiäna till Antiquiteternes excolerande. Published by G.E. Klemming. Stockholm: Kongl. Boktryckeriet P. A. Norstedt \& söner, 1886. "Bård Snäfellsasens saga". In De isländska sagorna: 2. bandet, Västlandssagor, 72103. I tolkning, med skaldevers och kommentar av A. Ohlmarks. Stockholm: Steinsvik, 1963. 
Ekedahl, Nils. “Johannes Schefferus (1621-1679)”. In Svenska historiker: Från medeltid till våra dagar, edited by Ragnar Björk and Alf W. Johansson, 103114. Stockholm: Norstedt, 2009.

Ellenius, Allan. "Johannes Schefferus and Swedish Antiquity”. Journal of the Warburg and Courtauld Institutes 20, no. 1/2 (1957): 59-74.

Eng, Torbjörn. Det svenska väldet: Ett konglomerat av uttrycksformer och begrepp från Vasa till Bernadotte. PhD diss. Uppsala: Uppsala universitet, 2001.

Eriksson, Gunnar. The Atlantic Vision: Olaus Rudbeck and Baroque Science. Canton: Science History Publications, 1994.

Eriksson, Gunnar. Rudbeck 1630-1702: Liv, lärdom, dröm i barockens Sverige. Stockholm: Atlantis, 2002.

Fewster, Derek. Visions of past Glory: Nationalism and the Construction of Early Finnish History. PhD diss. Helsinki: Finnish Literature Society, 2006.

Finlands medeltidsurkunder: 1, -1400. Published by Reinhold Hausen. Helsingfors: Statsarkivet, 1910.

Grafton, Anthony. What Was History?: The Art of History in Early Modern Europe. Cambridge: Cambridge University Press, 2012.

Gustafsson, Harald. “The Eighth Argument: Identity, Ethnicity and Political Culture in Sixteenth-Century Scandinavia." Scandinavian Journal of History 27, no. 2 (2002): 91-113.

Hadorph, Johan. Dahle Laghen: Then i forna tijder hafwer brukat warit öfwer alla Dalarna och them som in om Dala råmärken bode. Stockholm: Johan Georg Eberdt, 1676.

Hall, Patrik. Den svenskaste historien: Nationalism i Sverige under sex sekler. Stockholm: Carlsson, 2000.

Jensen, Ola W. Forntid $i$ historien: En arkeologihistorisk studie av synen på forntid och forntida lämningar, från medeltiden till och med förupplysningen. $\mathrm{PhD}$ diss. Göteborg: Institutionen för arkeologi, 2002.

Johnsen, Oscar Albert. Finmarkens politiske historie: aktmassig fremstillet. Kristiania: I kommission hos Jacob Dybwad, 1923. 
Jonae, Arngrimus. Crymogaea sive rerum islandicarum libri III. Hamburg: In Bibliopolio Heringiano, 1614.

Julku, Kyösti. Kvenland - Kainuunmaa. Oulu: Pohjoinen, 1986.

Juslenius, Daniel. Aboa vetus et nova: Vanha ja uusi Turku = Åbo förr och nu = Turku old and new. Translated by Tuomo Pekkanen, Virpi Seppälä-Pekkanen, Frans Johan Rabbe, Laura Mattsson, and Gerard McAlester. Helsinki: Suomalaisen Kirjallisuuden Seura, 2005.

Kidd, Colin. British Identities before Nationalism: Ethnicity and Nationhood in the Atlantic World, 1600-1800. Cambridge: Cambridge University Press, 1999.

Krook, Ragnar. “Österbottens ställning under Finlands förening med Sverige”. Historisk tidskrift för Finland 8, no. 1 (1923): 1-38.

Legnér, Mattias. Fäderneslandets rätta beskrivning: Mötet mellan antikvarisk forskning och ekonomisk nyttokult i 1700-talets Sverige. PhD diss. Helsingfors: Svenska litteratursällskapet i Finland, 2004.

Lehtinen, Erkki. Suomen varhaishistorian ja ristiretkikauden kuvasta uskonpuhdistusja suurvalta-aikana. Jyväskylä: Suomen Historiallinen Seura, 1968.

Lerbom, Jens. Svenskhetens tidigmoderna gränser: Folkliga föreställningar om etnicitet och rikstillhörighet i Sverige 1500-1800. Göteborg: Makadam förlag, 2017.

Liedgren, Jan. “Hadorph, Johan”. In Svenskt biografiskt lexikon: Band 17, edited by Erik Grill, 697-701. Stockholm: Norstedt, 1967-1969.

Lindberg, Bo. Den antika skevheten: Politiska ord och begrepp i det tidig-moderna Sverige. Stockholm: Kungl. Vitterhets historie och antikvitets akademien, 2006.

Lindroth, Sten. Svensk lärdomshistoria: Medeltiden, reformationstiden. Stockholm: Norstedt, 1975.

Lindroth, Sten. Svensk lärdomshistoria: Stormaktstiden. Stockholm: Norstedt, 1975.

Lönnroth, Harry, and Martti Linna. "Esipuhe”. In Johannes Messenius Suomen riimikronikka, edited by Harry Lönnroth and Martti Linna, 6-7. Helsinki: Suomalaisen Kirjallisuuden Seura, 2004.

Löw, Bengt. "Johannes Schefferus och hans Lapponia". In Johannes Schefferus' Lappland, published by Ernst Manker, 9-23. Stockholm: Gebers, 1956.

Löw, Gustav. Sveriges forntid i svensk historieskrivning: 1. Stockholm: Fritze, 1908. 
Magnus, Johannes: Goternas och svearnas historia. Translated by Kurt Johannesson.

Stockholm: Kungl. Vitterhets Historie och Antikvitets akademien, 2018.

Magnus, Olaus: Historia de gentibus septentrionalibus. Romae, 1555.

Manninen, Juha. "Den finska nationen i det svenska riket: Daniel Juslenius och Henrik Gabriel Porthans nationskonstruktioner”. In Maktens mosaik: Enhet, särart och självbild $i$ det svenska riket, edited by Max Engman and Nils-Erik Villstrand, 233-263. Stockholm: Atlantis, 2008.

Manninen, Juha. Valistus ja kansallinen identiteetti: Aatehistoriallinen tutkimus 1700luvun Pohjolasta. Helsinki: Suomalaisen Kirjallisuuden Seura, 2000.

Messenius, Johannes. Ex Johannis Messenii Scondia Illustrata, Tomus X. Stockholmiae: Typis Olavi Enaei, 1703.

Messenius, Johannes. "Finlands rimkrönika". In Johannes Messenius Suomen riimikronikka, edited by Harry Lönnroth and Martti Linna, 156-269. Helsinki: Suomalaisen Kirjallisuuden Seura, 2004.

Messenius, Johannes. Johannis Messenii Scondiae Illustrateae Tomus XIII. Stockholmiae: Literis Olavi Enaei, 1704.

Messenius, Johannes. Scondiae Illustratae volumen secundum, vel tomus XI. Stockholmiae: Olavi Enaei, 1703.

Niurenius, Olaus Petri. 'Lappland, eller beskrivning över den nordiska trakt, som lapparne bebo i de avlägsnaste delarne av Skandien eller Sverge; jämte svar på åtskilliga frågor rörande lapparne av Ericus Plantinus”. Bidrag till kännedom om de Svenska landsmålen och svenskt folkliv 17, no. 4 (1905): 7-28.

Nordin, Jonas. Ett fattigt men fritt folk: Nationell och politisk självbild i Sverige från sen stormaktstid till slutet av frihetstiden. PhD diss. Eslöv: Brutus Östlings bokförlag Symposion, 2000.

Nordström, Johan. Johannes Magnus och den götiska romantiken: Akademiska föreläsningar 1929. Published by Carl-Otto von Sydow. Stockholm: Michaelisgillet, 1975.

Norris, Matthew. A Pilgrimage to the Past: Johannes Bureus and the Rise of Swedish Antiquarian Scholarship, 1600-1650. PhD diss. Lund: Faculties of Humanities and Theology, Department of the History of Ideas, 2016. 
Nurmiainen, Jouko. 'Frågan om 'etnisk nationalism', nationell självbild och 1700-talets Sverige”. Translated by Charlotta Wolff. Historisk tidskrift för Finland 88, no. 3 (2003): 257-275.

Olsson, Harald. Johannes Messenius Scondia illustrata: Studier i verkets tillkomsthistoria och medeltidspartiets källförhållanden. $\mathrm{PhD}$ diss. Lund: Gleerup, 1944.

Orkneyinga saga: The History of the Earls of Orkney. Translated with an introduction by Hermann Pálsson and Paul Edwards. Harmondsworth: Penguin, 1981.

Rudbeck, Olof. Olaus Rudbecks Atlantica: Svenska originaltexten. 4 vols. Published by Axel Nelsson. Uppsala: Almqvist \& Wiksell, 1937-1950.

Ryymin, Teemu, and Per Pippin Aspaas. "Kvenbegrepet hos Henrik Gabriel Porthan". Arina 10 (2010): 45-72.

Schefferus, Johannes. Lapponia: Id est regionis lapponum et gentis nova et verissima descriptio. Francofurti: Christian Wolff, 1673.

Schück, Henrik. Johan Hadorph: Minnesteckning. Stockholm: Norstedt, 1933.

Schück, Herman. "Johannes Messenius (1579/80-1636)". In Svenska historiker: Från medeltid till våra dagar, edited by Ragnar Björk and Alf W. Johansson, 96-102. Stockholm: Norstedt, 2009.

Setälä, Emil Nestor. "Ein lappisches Wörterverzeichnis von Zacharias Plantinus". Suomalais-ugrilaisen seuran aikakauskirja 8 (1890): 85-104.

Sikeborg, Urban. "Baggars söner och halvgudar: Bureätten genom årtusendena". In Johan Bures släktbok, edited by Urban Sikeborg. Solna: Genealogiska föreningen, 2014 [Electronic version].

Sikeborg, Urban. "Om versionerna av Johan Bures släktbok samt deras innehåll och disposition”. In Johan Bures släktbok, edited by Urban Sikeborg. Solna: Genealogiska föreningen, 2014 [Electronic version].

Smith, Anthony D. Myths and Memories of the Nation. Oxford: Oxford University Press, 1999.

Steckzén, Birger. Birkarlar och lappar: En studie i birkarleväsendets, lappbefolkningens och skinnhandelns historia. Stockholm: Almqvist \& Wiksell, 1964. 
Sturluson, Snorre: "Ynglinga-Sagan”. In Konunga-boken, eller, Sagor om ynglingarne och Norges konungar intill år 1177:1, edited by Hans Olof Hildebrand Hildebrand, 5-55. Örebro: Abr. Bohlin, 1869.

Sörlin, Sverker. Framtidslandet: Debatten om Norrland och naturresurserna under det industriella genombrottet. PhD diss. Stockholm: Carlsson, 1988.

Tornaeus, Johannes. ”Berättelse om Lapmarckerna och deras tillstånd”. Nyare bidrag till kännedom om de Svenska landsmålen och svenskt folkliv 17, no. 3 (1900): 964.

Torstendahl, Rolf. Källkritik och vetenskapssyn i svensk historisk forskning 1820-1920. PhD diss. Stockholm: Svenska bokförlaget, 1964.

Urpilainen, Erkki. Algot Scarin ja gööttiläisen historiankirjoituksen mureneminen Ruotsissa 1700-luvun alkupuolella. PhD diss. Helsinki: Suomen Historiallinen Seura, 1993.

Villstrand, Nils Erik. Finlands svenska historia 2: Riksdelen: Stormakt och rikssprängning 1560-1812. Helsingfors: Svenska litteratursällskapet i Finland, 2009.

Wallette, Anna. Sagans svenskar: Synen på vikingatiden och de isländska sagorna under 300 år. PhD diss. Malmö: Sekel, 2004.

Wargius, Martinus. Brevis et succincta commendatio Bothnia orientalis. Aboae: Petrus Wald, 1643.

Widenberg, Johanna. Fäderneslandets antikviteter: Etnoterritoriella historiebruk och integrationssträvanden i den svenska statsmaktens antikvariska verksamhet ca. 1600-1720. PhD diss. Uppsala: Uppsala universitet, 2006.

Wiklund, Karl Bernhard. "Förord”. Bidrag till kännedom om de Svenska landsmålen och svenskt folkliv 17, no. 4 (1905): 3-5.

Wikström, Sten. Norrbotten: En studie om gränser. Luleå: Tornedalica, 1982. 